\title{
A New Solution for an Electrochemical Modification of Titanium Surface
}

\author{
S. Kyrylenkoㄹ, O. Oleshkoㄹ, F. Warchoł², Ye. Husak ${ }^{1}$, M. Basiaga ${ }^{3}$, A. Kazek-Kesik², \\ G. Dercz ${ }^{4}$, M. Pogorielovi, ${ }^{1,}$ W. Simka ${ }^{2, \dagger}$ \\ 1 Medical Institute, Sumy State University, 2, Rymsky-Korsakov St., 40007 Sumy, Ukraine \\ 2 Silesian University of Technology, Faculty of Chemistry, 44-100 Gliwice, Poland \\ 3 Silesian University of Technology, Faculty of Biomedical Engineering, 41-800 Zabrze, Poland \\ ${ }^{4}$ Institute of Materials Science, University of Silesia, 41-500, Chorzów, Poland
}

(Received 25 September 2020; revised manuscript received 15 December 2020; published online 25 December 2020)

\begin{abstract}
Dental/osseous implants manufactured of titanium (Ti) have become a routine and affordable method in medical practice. To increase the overall safety and longtime stability of the implants further, the sophisticated approaches have been investigated in order to supply the implants with the bioactive surface layers. They have to serve two purposes: to increase the osseointegration capacity of the implants and to reduce the chances of bacterial growth and formation of bacterial biofilms leading to periimplantitis. Plasma electrolytic oxidation (PEO) is becoming a promising method to introduce functionalized surface layers on a metal substrate. Various PEO protocols have been suggested in order to achieve better biocompatibility of the dental implants and to increase their resistance to bacterial infections. It was also suggested that the PEO layers could increase resistance to corrosion on the surfaces of metallic implants. The dynamic processes running on the surface of Ti during the PEO processing still require efforts to fully understand the molecular mechanisms of the formation of hard and porous oxide surface layers. We and others have already shown that addition of a chelating agent to the bath electrolyte leads to better outcomes in the morphology and functional characteristics of the implants. Here we report in depth characterization of the PEO parameters and the produced PEO surface layers using the bath electrolyte containing another widely used chelating agent, nitrilotriacetic acid (NTA) along with potassium phosphate and calcium formate. The results will contribute to further understanding the mechanisms of the PEO process and to establishing routine protocols for commercial exploitation of the PEO method.
\end{abstract}

Keywords: Plasma electrolytic oxidation, Titanium, Bioactive surface, Dental implant, Biocompatibility, Scanning electron microscopy, Energy dispersive X-ray spectroscopy, Scratch test, Simulated body fluid test, Contact angle measurement.

DOI: 10.21272/jnep.12(6).06038

PACS numbers: 81.15.Pq, 87.85.J, 87.64.Ee

\section{INTRODUCTION}

Plasma Electrolytic Oxidation (PEO) has emerged as a method of choice to modify the surfaces of metallic implants and to supply them with features necessary for biomedical applications [1,2]. The PEO process setup is similar to more routine anodization with the difference in the choice of higher voltage. The electrochemical parameters are chosen such that after the initial formation of a dielectric oxide layer, the applied voltage is high enough to break the dielectric barrier and to establish continuous generation of plasma sparks with consequent formation of relatively thick microporous oxide layers [3]. Modification of the PEO parameters such as voltage and current density, as well as quantitative and qualitative content of the bath electrolyte can lead to modifications in the morphology and elemental composition of the coating layers [4]. The PEO has already found many applications in technical and biomedical fields. Thus, the PEO layers were targetedly enriched with hydroxyapatite [5], a principal mineral component of bone tissue which leads to better osteoconductive and osteogenic properties. The PEO surfaces were made suitable for successful bone integration [6] and to support proliferation of mesenchymal stem cells [7]. On the other hand, the PEO layers were rendered bacteriostatic properties via incorporation of $\mathrm{Ag}$ and $\mathrm{Cu}$ nanoparticles $[8,9,10]$. The surface morphology of the PEO layers can also be modified in order to achieve the desired structure which could improve cellular adhesion and viability [11]. The PEO process can be used to supply the surface layers with e.g. bioactive glass for better osseointegration [12] or basalt mineral fibers for improved wear resistance [13]. It can also be used in technical fields to increase corrosive resistance of steel pipes [14]. Overall, the PEO is being actively exploited to introduce functional elements into coatings on biomaterials and beyond biomedical applications [15].

Components of the PEO bath electrolyte preferentially should form complexes in order to improve robustness of the PEO processing. We and others $[16,4]$ showed that addition of ethylenediaminetetraacetic acid, a widely used chelating agent (ChA), can dramatically increase reproducibility of the PEO process. Nitrilotriacetic acid (NTA) is another widely used ChA. It is employed e.g. as a principal component in the His-tag protein purification columns [17]. Being an active ChA, the NTA coordinatively binds to polyvalent metal ions with its donor groups, forming a cage like structure. The ChAs have multiple dents, each containing specific chemical groups, which form multiple bonds with the target metal ion. These dents can be flexible, giving ChAs

\footnotetext{
*m.pogorielov@gmail.com

$\dagger$ wojciech.simka@polsl.pl
} 
highly reactive and versatile binding possibilities not only to form complexes with metal ions, but also to bind with metal oxide surface [18]. We recently showed that the NTA can improve deposition of $\mathrm{Ag}$ nanoparticles into the PEO surface layers on titanium implants to render them the bacteriostatic properties [10]. Here we continued to investigate the positive effects of addition of the NTA into the PEO bath electrolyte containing potassium phosphate and calcium formate. We investigated the effect of the NTA in details and showed that chelating complexes by the NTA lead to improvements of the overall productivity and reproducibility of the PEO processing of the titanium specimens.

\section{MATERIALS AND METHODS}

\subsection{Ti Specimens}

Commercially pure titanium (grade 4) in the form of cylinders with a diameter of $10 \mathrm{~mm}$ and a height of $4 \mathrm{~mm}$ was used. Before the anodizing process, the sample surfaces were ground with sandpaper ( $\mathrm{SiC})$ with increasingly fine grades: 400, 600 and 800 . The samples were degreased in isopropanol, in an ultrasonic cleaner for $3 \mathrm{~min}$, rinsed in DEMI water, and air-dried.

\subsection{Plasma Electrolytic Oxidation (PEO)}

The PEO was carried out using a KIKUSIU PWR800H (Japan) high voltage power supply, controlled with a PC with Wavy software. The first stage of the research was to record the $(U, i)=f(t)$ curves in the experimental bath electrolytes, the composition of which is given in Table 1 . The recording was carried out at three current densities: 50, 100 and $150 \mathrm{~mA} / \mathrm{cm}^{2}$. The processing time was $5 \mathrm{~min}$. The solution was stirred during the process using a magnetic stirrer. The process temperature was $15{ }^{\circ} \mathrm{C}$. After the PEO anodizing process, the samples were rinsed with a stream of DEMI water, air dried and packed. For easy identification of samples as well as process variable parameters, the following sample designation was adopted: Ti-X-Y-Z, where X stands for bath electrolyte; $\mathrm{Y}$ signifies voltage and $\mathrm{Z}$ current density. For example, the sample number Ti-A450-150 was anodized in bath electrolyte A, with an end voltage of $450 \mathrm{~V}$ and a current density of $150 \mathrm{~mA} / \mathrm{cm}^{2}$.

Table 1 - Content of the bath electrolytes used in the study

\begin{tabular}{|l|l|l|l|}
\hline Bath electrolyte & NTA & $\mathbf{K H}_{2} \mathbf{P O}_{4}$ & $\mathbf{C a}(\mathrm{HCOO})_{2}$ \\
\hline A & 1.28 & 0.25 & 0.5 \\
\hline B & 2.56 & 0.5 & 1 \\
\hline
\end{tabular}

\subsection{Scanning Electron Microscopy (SEM) with Energy Dispersive X-ray (EDX) Spectroscopy}

Morphology of the PEO surfaces was studied by scanning electron microscopy (SEM) as described [4] using Hitachi S-3400N equipment (Tokyo, Japan) with an accelerating voltage of $15 \mathrm{kV}$. Detailed examination of the chosen samples was made using Phenom ProX microscope at an accelerating voltage of $15 \mathrm{kV}$. Chemical composition of the surface layer was analyzed by energy dispersive X-ray (EDX) spectroscopy using PhenomProX equipment. The distribution of pore sizes was measured using Image-Pro software (Media Cybernetics, USA).

\subsection{Simulated Body Fluid (SBF) Immersion Test}

The test of hydroxyapatite nucleation in a simulated physiological solution (SBF) on anodized titanium was carried out in order to determine its potential bioactivity. The SBF immersion aimed at determining the influence of surface physicochemistry on increasing the rate of crystallization of apatites on it. The samples were exposed to SBF in a volume of $50.0 \mathrm{ml}$ per sample at $37^{\circ} \mathrm{C}$ temperature with weekly changes of the fluid for 4 weeks. The surfaces were observed after each week in immersion.

\subsection{XRD Diffraction}

The XRD was done as described [4] with X'Pert Philips PW 3040/60 diffractometer, operated at $30 \mathrm{~mA}$ and $40 \mathrm{kV}$, equipped with a vertical goniometer and Eulerian cradle. The XRD pattern was registered in $2 \theta$ region of $10-140^{\circ}$ using $\mathrm{CuKa}_{1,2}$ radiation $\left(\lambda_{\text {CuKa1 }}=1.54056 \AA\right.$ and $\left.\lambda_{\text {CuKa2 }}=1.54443 \AA\right)$ for the incident angle $a$ of 0.25 degrees (GIXD - grazing incidence X-ray diffraction).

\subsection{Contact Angle Measurements}

The $2 \mu$ d drop of water was applied to the surface of the sample and the contact angle was observed as described [19] using OCA 15EC optical contact angle measuring instrument and contour analysis systems (Data Physics, Filderstadt, Germany) with $2 \mu$ drops of distilled water.

\subsection{Adhesion - Scratch Test}

Adhesion of the PEO layer to the metal substrate was evaluated using the scratch test as described [4]. Briefly, an open platform equipped with the MicroCombi-Tester by CSM in accordance with the standard was used. The test consisted in making a scratch with the use of a penetrator, a Rockwell diamond cone, with a gradual increase in the normal force for loading the penetrator. The critical force, which is a measure of adhesion, is the smallest normal force that causes the coating to lose adhesion to the substrate. To assess the value of the critical force $L c$, the record of the friction force and the coefficient of friction as well as microscopic observations made on the optical microscope, which is an integral part of the Platform, were used. The tests were performed with the increasing loading force of $0.03 \div 25 \mathrm{~N}$ and with the following operating parameters: loading speed $10 \mathrm{~N} / \mathrm{min}$, table speed $1.0 \mathrm{~mm} / \mathrm{min}$, scratch length $\sim 2.5 \mathrm{~mm}$.

\section{RESULTS AND DISCUSSION}

\subsection{Functions $(U, i)=f(t)$}

The voltage-time curves acquired during the studied PEO processes are presented in Fig. 1. The curves exhibit shapes characteristic of galvanostatic anodizing conditions with an initial fast voltage increase corresponding to the growth of a barrier oxide layer and subsequent voltage oscillations at a reduced slope associated with the initiation of plasma microdischarges [20]. 
Based on the analysis of the curves $(U, i)=f(t)$, it was found that the oxidation process of titanium in baths containing only complexing agents and calcium hydroxide did not proceed properly (not shown). The obtained curves indicated that the course of the process was not stabilized, and the assumed final voltage within 5 min was not achieved. Increasing the process time would not be satisfactory as the voltage was kept at a very low level. Changing the source of calcium from hydroxide to formate did not bring the expected result either (not shown). As in the previous case, the recorded curves were "jagged" and the voltage did not rise to the assumed level. The process under such conditions would be difficult to implement and the project goal would not be achieved.

After addition of a source of phosphorus $\left(\mathrm{KH}_{2} \mathrm{PO}_{4}\right)$ to the bath, the titanium oxidation process started to proceed as expected. Each of the curves recorded in bath electrolytes A (Fig. 1) and B (not shown) looked similar, regardless of the current density used. At the beginning of the process, the voltage increased linearly with the rate of rise depending on the current density. The higher the current density, the faster this process proceeded. Then, after reaching the breakdown voltage of the oxide layer (a process in the PEO regime), the rate of voltage increase decreased and lost its linear character. The value of the breakdown voltage of the oxide film depended mainly on the chemical composition of the bath used. On the recorded curves $(U, i)=f(t)$, one can notice the inflection points at which the voltage rise rate changes. The presence of these points results from a change in the formation mechanism of the oxide layer on titanium, as well as from a change in its physicochemical properties (thickness, composition). The nature is also changed by electric discharges (sparks) on the titanium surface. Therefore, it can be expected that the oxidation of titanium in these areas will result in obtaining an oxide film with a different morphology.

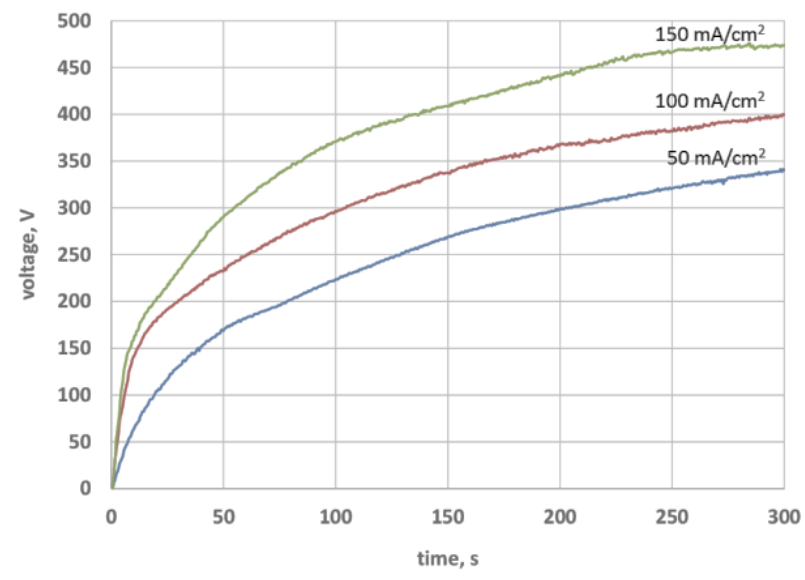

Fig. 1 - A representative picture showing the curves $(U, i)=f(t)$ recorded in the bath electrolyte $A$ at the set current densities of $50 \mathrm{~mA} / \mathrm{cm}^{2}, 100 \mathrm{~mA} / \mathrm{cm}^{2}$ and $150 \mathrm{~mA} / \mathrm{cm}^{2}$ as indicated

Depending on the chemical composition of the bath and the current density, different end voltages were obtained in the titanium oxidation process. The rate at which the end voltage was reached in 5 min depended on the current density used. It should be noted that the voltage of about $500 \mathrm{~V}$ was obtained only by using a current density of $150 \mathrm{~mA} / \mathrm{cm}^{2}$. Based on the analysis of the curves $(U, i)=f(t)$, the following parameters of the oxidation process were selected: the voltage and current density for baths A and B. It is known that Ti requires very high energy for its oxidation [21]. The voltage was selected so that it was in the middle of a given range in which the process was carried out according to the oxidation mechanism.

\subsection{SEM Analysis}

Fig. 2 shows SEM images of titanium samples subjected to the oxidation process in selected solutions. The selection of the oxidation parameters was made on the basis of previously recorded curves $(U, i)=f(t)$. These images were analyzed in terms of the quality of the obtained surface, as well as potential use as target coatings on dental implants. The coatings should have a porous structure and should also be free from cracks. During the oxidation process, regardless of the bath used and the current density, the assumed voltage was reached within $5 \mathrm{~min}$. Upon reaching this voltage, the current dropped to a few $\mathrm{mA}$, which was normal.

The coatings produced in bath electrolyte $\mathrm{A}$ at a voltage of $300 \mathrm{~V}$ mirrored the surface of the substrate regardless of the current density used. The most interesting structures were obtained using the voltage and current density of $350 \mathrm{~V}$ and $100 \mathrm{~mA} / \mathrm{cm}^{2}$, as well as $450 \mathrm{~V}$ and $150 \mathrm{~mA} / \mathrm{cm}^{2}$, respectively. Cracks appeared on the surface of the sample at a voltage of $470 \mathrm{~V}$. The following samples were selected for further research: Ti-A-350-100 and Ti-A-450-150.

The most interesting titanium surface structures were obtained in bath electrolyte B. In this bath electrolyte, virtually every applied voltage and current density resulted in uniform coatings covering the entire surface. The coatings produced at a current density of $100 \mathrm{~mA} / \mathrm{cm}^{2}$ were characterized by the most pronounced morphology, which indicates a large development in their $3 \mathrm{D}$ structure.

It is well known that the size and duration of the microdischarges tend to increase with the PEO processing time producing larger pores [21]. It was also reported that the pore size of PEO coatings increased with the increase in the applied voltage [22]. Therefore, the following samples were selected for further research: Ti-B-300-100, Ti-B-400-100 and Ti-B-450-100.

Biomimetic coatings show their osseointegration properties in large part due to the optimal distribution of the pore sizes [23]. We therefore measured the pore sizes in the selected samples (Fig. 3). The majority of pores (around 50-60\% of all pores) were within 0.1-1 micron $(\mu \mathrm{m})$ in size. The PEO with electrolyte B gave rise also to a substantial amount (up to $20 \%$ ) of larger pores at 1 $5 \mu \mathrm{m}$ in size. The pores of this size were less abundant in case of the bath electrolyte $\mathrm{A}$. It is known that microporous structure with a pore size of $3-4 \mu \mathrm{m}$ exhibits high osteogenic and angiogenic activities [24]. The pores larger than $5 \mu \mathrm{m}$ were present at an amount of only a few percent, with a clear tendency to become a minuscule amount with a pore size larger than $25 \mu \mathrm{m}$. The smaller size pores of less than $0.1 \mu \mathrm{m}$ were also present in a substantial amount (up to $20 \%$ ) in case of electrolyte B. However, with electrolyte A the pores of this size 
were dominant (around $50 \%$ ) in case of the sample Ti-A350-100, while with increasing voltage and current they became less abundant (sample Ti-A-450-150). It was reported that the ultrafine pores of around $0.1 \mu \mathrm{m}$ in size can participate in enhancing cellular responses [25].

Interaction between the surface of the implant and the surrounding tissues, e.g. bone, depends on the pore morphology and overall unevenness of the surface [26]. The surface-to-bone interface requires pores of various sizes, also it still remains elusive which surface features are more effective in regulating particular cell functions [25].

As a result, the selected samples can potentially be used to modify dental implants. Due to the fact that the produced oxide layers can still differ in terms of quality, they have been subjected to further detailed analysis.

\subsection{EDX Investigations}

The EDX tests of selected samples were carried out
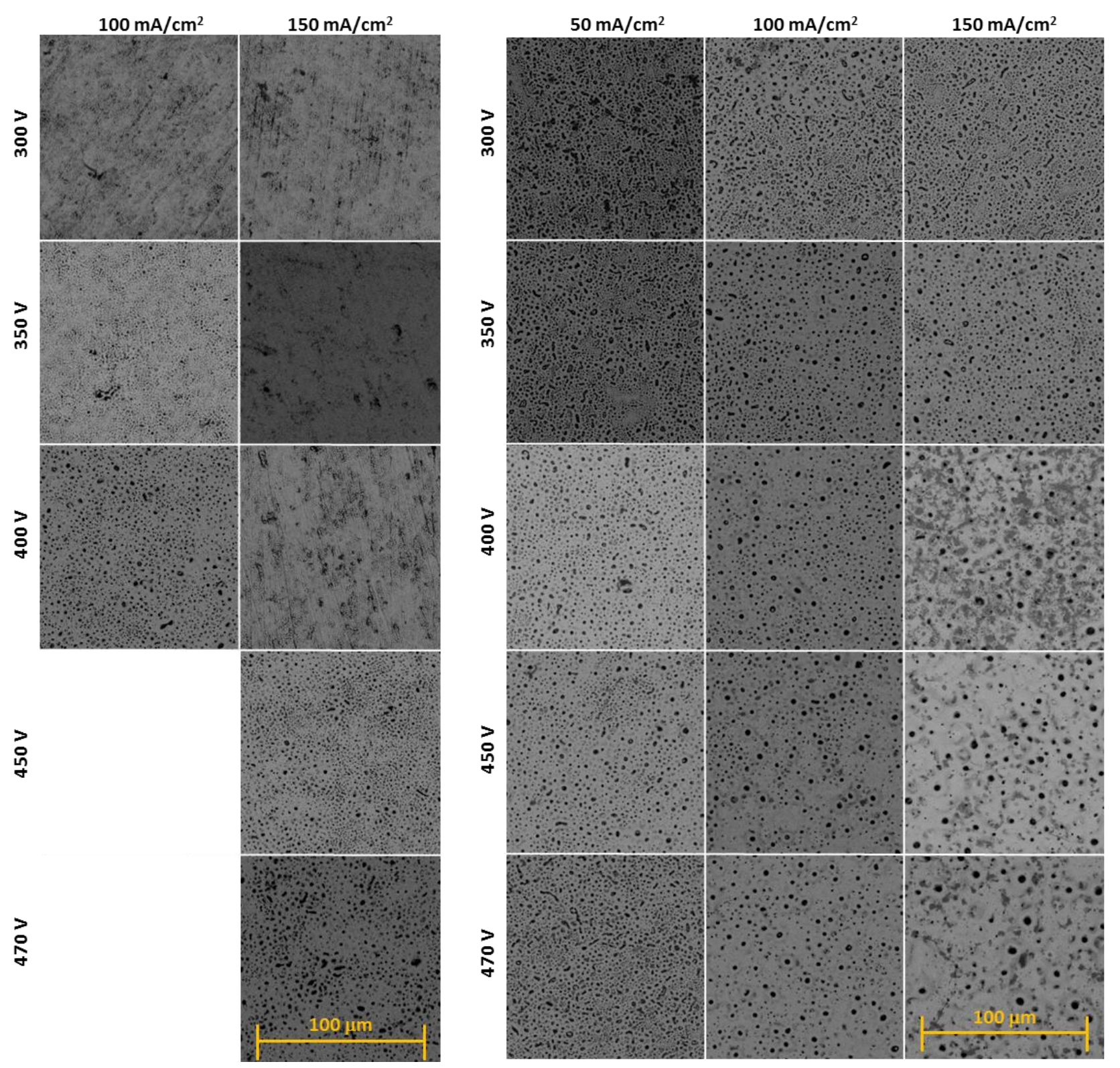

Fig. 2 - Representative SEM images of the PEO anodized titanium surfaces in the bath electrolytes A (left panel) and B (right panel). Electrochemical parameters (voltage and current density) were used as indicated using the Phenom ProX electron microscope (Fig. 4). The oxide layers on the PEO surface of the samples TiA-350-100 and Ti-A-450-150 were significantly enriched with bath components $\mathrm{P}$ and $\mathrm{Ca}$. The EDX spectrum also showed the peaks of oxygen and titanium, i.e. components of the oxide film. Judging by the intensity of the Ca peak, the content of this element is greater in the oxide layer than in the case of the oxidized sample at lower voltage.

Similarly, the oxide layers of the samples Ti-B-300100, Ti-B-400-100 and Ti-B-450-100 were also enriched with bath components $\mathrm{P}$ and $\mathrm{Ca}$. The EDX spectrum also showed the peaks of oxygen and titanium, i.e. components of the oxide film. The intensity of the $\mathrm{Ca}$ peak indicated that the content of $\mathrm{Ca}$ in the PEO surface layer becomes higher with an increase in voltage. Analysis of the $3 \mathrm{D}$ images revealed that the sample surface becomes more extensive with increased voltage. 

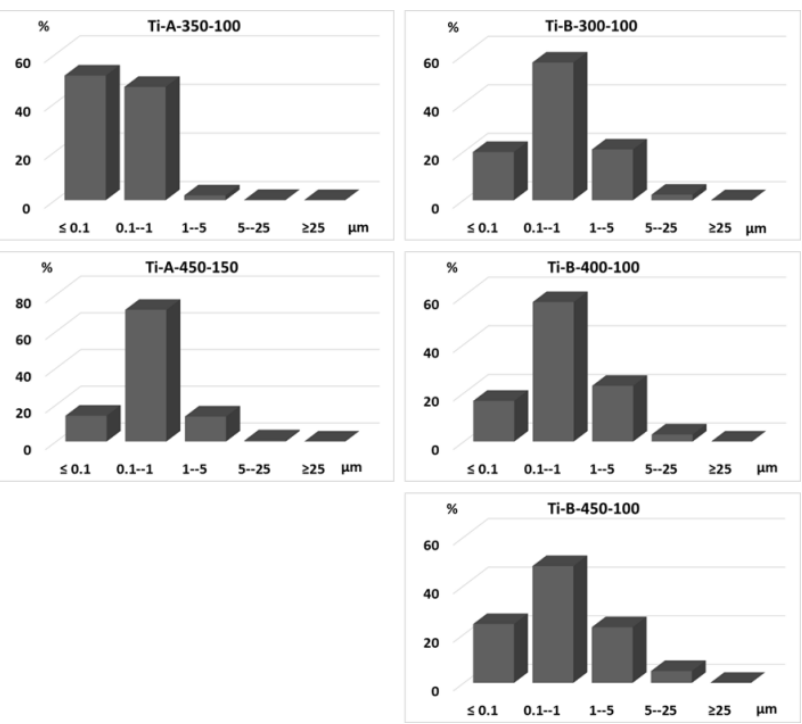

Fig. 3 - Distribution of pore sizes in the selected PEO treated Ti surfaces

\subsection{Potential Bioactivity Investigated in the SBF Test}

Fig. 5 shows representative SEM images of the samples that were exposed to SBF for 4 weeks. Initial bioactivity studies in the SBF physiological solution were aimed at determining the influence of the physicochemical features of the PEO surfaces on the rate of crystallization of apatite on them. The surfaces were observed after each week.

On the pure titanium surface, no increase in apatite was observed after 4 weeks of exposure to SBF (not shown). Appearance of fine particles was observed on the surfaces of the samples Ti-A-350-100, Ti-A-450-150 and Ti-B-300-100, the amount of which did not increase with time (not shown). We concluded that these surfaces do not support apatite crystallization process.

On the surfaces of the sample Ti-B-400-100, clear crystallites were visible already after two weeks in incubation (not shown). After three weeks, the surface was covered with a thick, cracking layer of apatite. This layer fell off the sample in the following week. We concluded that this surface favors the crystallization of apatite.

On the surface of the sample Ti-B-450-100, the presence of crystallites was clearly visible (Fig. 5). The surface was almost completely covered with the mineralized apatite already after the first week of incubation. Appearance of the precipitates on the PEO surfaces indicated that the nucleation of apatite has actively occurred. With increasing immersion time, the size and quantity of the precipitates increased, which was in line with previously published results [27]. After three weeks in incubation, the surfaces were covered with thick, cracking layers of apatite. Detailed investigation revealed that the pores were nearly sealed by numerous apatite grains grown around them. Once the apatite nuclei are formed, they can grow spontaneously by consuming calcium and phosphate ions from the surrounding fluid. The rate of apatite development on the surface is determined by the rate of apatite nucleation [27]. Notably, the apatite layers fell off the sample in the following (fourth) week. Overall, this indicated that the PEO surface Ti-B-450-100 favors the crystallization of apatite.

The SBF may contribute to the formation of specific functional groups such as $\mathrm{Ti}-\mathrm{OH}$ groups. These surface functional groups with a negative charge interact with the positive calcium ions in the fluid, forming calcium compounds such as calcium titanate. In turn, the formed amorphous calcium compounds reveal a positive charge which binds to negative phosphate ions in the fluid, forming an amorphous calcium phosphate, which later crystallizes into bonelike apatite [27, 28].

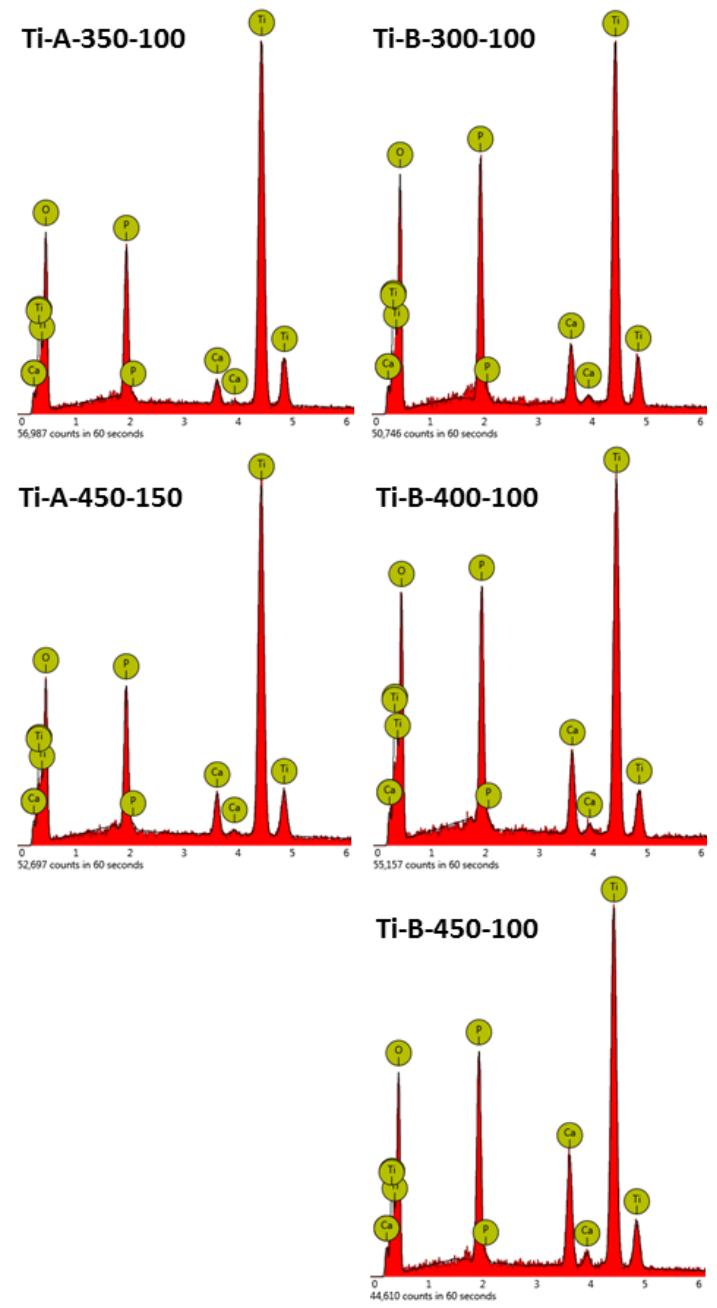

Fig. 4 - EDX spectra of the selected PEO modified samples

Generally, it is believed that biomaterials should preferably have surfaces with porous and rough morphology. Thus, pores can facilitate anchorage of the implants to the bone tissues. They can also act as nucleation sites for the formation of bone tissue elements, and abundant pores can delay saturation of nucleation sites for the precipitation of apatite [27].

In conclusion, this assay was carried out in order to increase bioactivity of the PEO surface layers. We assumed that the bioactivity could be increased by creating a porous oxide layer containing calcium, phosphorus and amino groups on the titanium surface. Such a combination of the properties of the oxide layer should lead to acceleration of the osseointegration processes of titani- 
um implants. We concluded that the samples Ti-B-400100 and Ti-B-450-100 were the most amenable for bioactivity and for these two samples, the additional investigation with the EDX was carried out (see below). It is of note here that the results of the SBF test should be interpreted with care. Such in vitro simulations are not always conclusive and sometimes may contradict the results of biological studies. The genuine biological activity of the PEO surfaces in vivo depends on many parameters, and therefore requires further investigations.

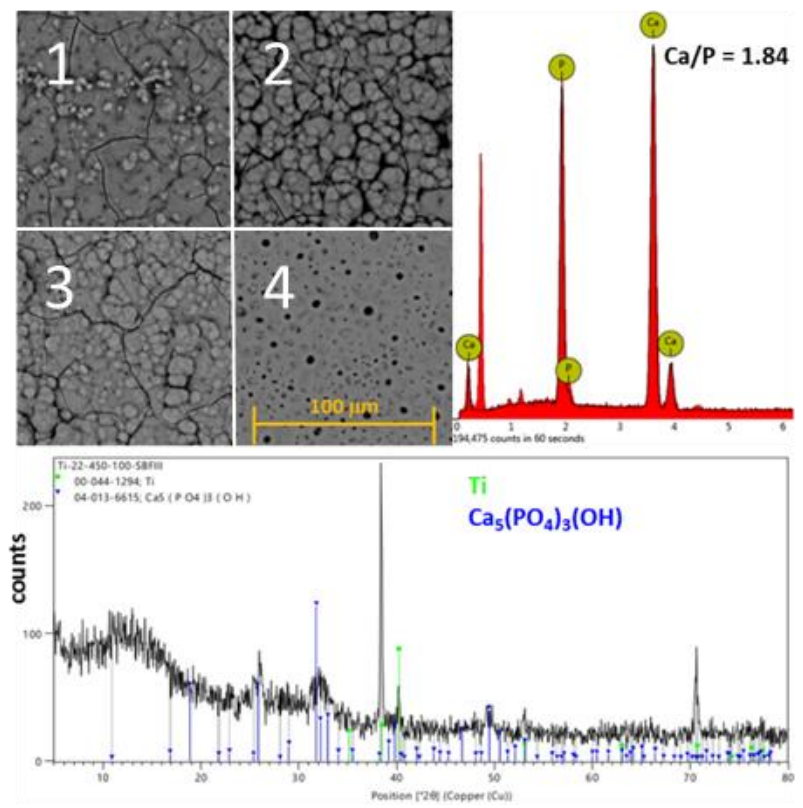

Fig. 5 - Representative SEM images showing the Ti-B-450-100 sample surface after the bioactivity test in the SBF solution for 4 consecutive weeks, numbered from one to four (upper left panel); the corresponding EDX spectrum of the same sample after three-week exposure in the SBF solution (upper right panel); and the XRD diffractograms recorded for the same sample after three weeks of immersion in the SBF solution (lower panel)

\subsection{SEM-EDX Analysis of the Selected Samples after the Test in the SBF Solution}

In order to confirm the crystallization of apatite on the surface of titanium subjected to the PEO process, the selected samples were analyzed for their elemental composition ( $\mathrm{Ca} / \mathrm{P}$ ratio). SEM and EDX examinations were performed using the Phenom ProX scanning electron microscope.

Table 2 - The $\mathrm{Ca} / \mathrm{P}$ atomic ratio calculated on the basis of the EDX analysis in the sediment present on the samples after three weeks of incubation in the SBF test

\begin{tabular}{|l|l|}
\hline Sample & $\mathbf{C a} / \mathbf{P}_{\text {at }}$ \\
\hline Ti-B-400-100-SBF & 0.22 \\
\hline Ti-B-450-100-SBF & 1.84 \\
\hline
\end{tabular}

The representative images of the SEM-EDX are shown in Fig. 5, upper right panel. We found that for the sample Ti-B-400-100, the ratio $\mathrm{Ca} / \mathrm{P}$ was close to the substrate and amounted to 0.22 (Table 2). In the case of the sample Ti-B-450-100, the ratio of calcium to phosphorus was 1.84 , which was very close to the atomic ratio of calcium to phosphorus in hydroxyapatite, the main mineral component of the bone tissue. We speculate that the low $\mathrm{Ca} / \mathrm{P}$ value in the former sample was due to the spontaneous detachment of the apatite layer after its initial deposition which reached the thickness incompatible with its mechanical stability.

\subsection{XRD Diffraction of the Selected PEO Surfaces after the SBF Immersion Test}

The analysis of the phase composition of the PEO surfaces after three weeks of immersion in the SBF solution for the sample Ti-B-450-100 (Fig. 5, lower panel) and the sample Ti-B-400-100 (not shown) was carried out. It was found that crystalline hydroxyapatite $\mathrm{Ca} 5\left(\mathrm{PO}_{4}\right)_{3}(\mathrm{OH})$ may be present on the surface of the Ti-B-400-100 sample in the formed apatite layer. The presence of a phase with an internally disordered structure does not allow an unambiguous determination of the phases containing a given calcium phosphate. Surface imaging using SEM clearly shows the formation of an apatite layer. However, on the basis of the conducted research, it cannot be unequivocally stated that in the formed apatite layer on the surface of the Ti-B-450-100 sample there are crystalline calcium phosphates, including hydroxyapatite. Single diffraction reflections ranging from $20^{\circ} 2$ Theta to $38^{\circ} 2$ Theta may come from phases containing amorphous or amorphous-crystalline titanium oxides and selected calcium phosphates. In order to characterize the obtained layers, it would be advantageous to use additional instrumental techniques, including X-ray photoelectron spectroscopy. For both samples, diffraction reflections for titanium were recorded. The broadening of the recorded signals for titanium indicates the formation of nonstoichiometric titanium oxides.

\subsection{Measurement of the Contact Angle}

The hydrophilicity of the obtained PEO surface layers was evaluated in the contact angle assay (Fig. 6). The contact angle characterizes the degree of intermolecular interactions of a solid surface with a water droplet and describes the wettability of the surface [29].

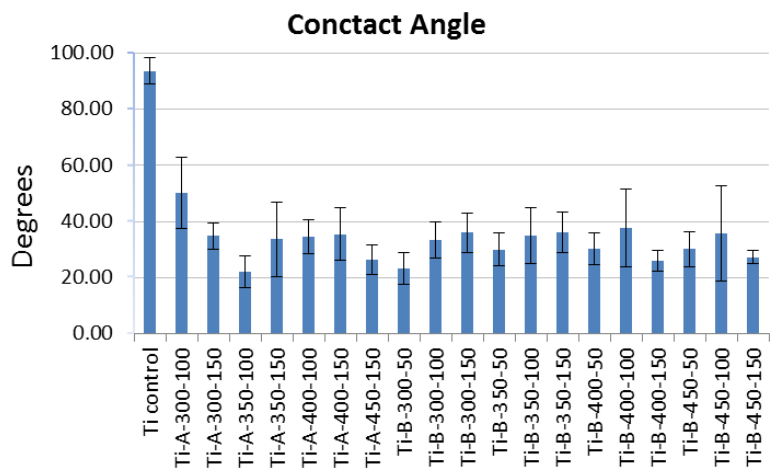

Fig. 6-Graphical results of the measurements of the contact angle. Please note a dramatic reduction in the value of the contact angle in all PEO treated samples in relation to untreated Ti control specimen 
Generally, the contact angle higher than $90^{\circ}$ indicates a hydrophobic surface, while angles less than $90^{\circ}$ are considered hydrophilic. The test was done with a $2 \mu \mathrm{l}$ drop of distilled water. This demonstrated that all the PEO surfaces obtained had dramatically increased hydrophilicity in comparison to the control bare Ti sample. The presence of $\mathrm{P}$ on the obtained PEO surfaces, revealed by the EDX analysis (Fig. 4), could have played a role in the mechanism of the increase in hydrophilicity. It is known that the presence of $\mathrm{P}$ in the structure of the surface is one of the fundamental prerequisites to obtain surfaces with high hydrophilicity [30]. Overall, this suggested that the PEO treatment led to increased potential biocompatibility of the implant surfaces.

\subsection{Scratch Test}

Different values of the critical forces $L c_{1}$ and $L c_{2}$ were found depending on the application parameters (Fig. 7). The sample Ti-B-450-100 was characterized by the highest adhesion, where the value of the critical force $L c_{2}=6.15$. In each case, no acoustic emission was found,

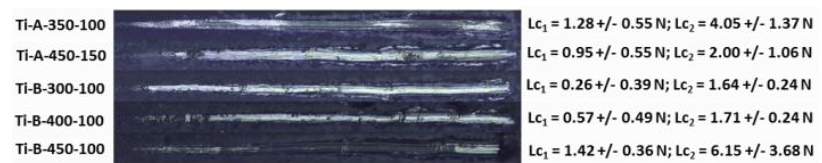

Fig. 7 - Representative pictures showing the results of the scratch test. The right panel shows quantitative results of the scratch test demonstrating adherence of the PEO layer to the Ti metal substrate, where $L c_{1}$ is the force applied on the intender at the initial damage to the layers and $L c_{2}-$ at the complete breakup of the layer

\section{REFERENCES}

1. D.V Mashtalyar, K.V Nadaraia, A.S. Gnedenkov, I.M. Imshinetskiy, M.A. Piatkova, A.I. Pleshkova, E.A. Belov, V.S. Filonina, S.N. Suchkov, S.L. Sinebryukhov, S.V Gnedenkov, Materials 13, 4121 (2020).

2. T.O.B. Polo, W.P. da Silva, G.A.C. Momesso, T.J. LimaNeto, S. Barbosa, J.M. Cordeiro, J.S. Hassumi, N.C. da Cruz, R. Okamoto, V.A.R. Barão, L.P. Faverani, Sci. Rep. 10, 10000 (2020).

3. M. Rizwan, R. Alias, U.Z. Zaidi, R. Mahmoodian, M. Hamdi, J. Biomed. Mater. Res. - Part A 106, 590 (2018).

4. S. Kyrylenko, F. Warchoł, O. Oleshko, Y. Husak, A. Kazek-Kessik, V. Korniienko, V. Deineka, M. Sowa, A. Maciej, J. Michalska, A. Jakóbik-Kolon, I. Matuła, M. Basiaga, V. Hulubnycha, A. Stolarczyk, M. Pisarek, O. Mishchenko, M. Pogorielov, W. Simka, Mater. Sci. Eng. C 119, 111607 (2021).

5. M. Mardali, H. Salimijazi, F. Karimzadeh, C. Blawert, B. J. C. Luthringer-Feyerabend, M. Fazel, B. Safarbali, ACS Omega 5, 24186 (2020).

6. M. Thukkaram, R. Coryn, M. Asadian, P.S. Esbah Tabaei, P. Rigole, N. Rajendhran, A. Nikiforov, J. Sukumaran, T. Coenye, P. Van Der Voort, G. Du Laing, R. Morent, A. Van Tongel, L. De Wilde, P. De Baets, K. Verbeken, N. De Geyter, ACS Appl. Mater. Interfaces 12, 30155 (2020).

7. N.G. Plekhova, I.N. Lyapun, E.I. Drobot, D.V. Shevchuk, S.L. Sinebryukhov, D.V. Mashtalyar, S.V. Gnedenkov, Bull. Exp. Biol. Med. 169, 147 (2020).

8. O. Oleshko, V. Deineka V, Y. Husak, V. Korniienko, O. Mishchenko, V. Holubnycha, M. Pisarek, J. Michalska, A. Kazek-Kęsik, A. Jakóbik-Kolon, W. Simka, M. Pogorielov, Materials 12, 3742 (2019). which proves that the bonding energy between the coating and the substrate was too low. Regardless of the sample type, a continuous plastic perforation of the layer was also found. In addition, different values of the critical force for a particular measurement were observed, which may most probably indicate a different layer thickness or the lack of plane-parallelism of the sample.

\section{CONCLUSIONS}

Addition of NTA to bath electrolyte for treatment of titanium samples with $\mathrm{PEO}$ in bath electrolyte containing $\mathrm{KH}_{2} \mathrm{PO}_{4}$ and $\mathrm{Ca}(\mathrm{HCOO})_{2}$ improves the resulting PEO surfaces. The most significant improvements are signified by the formation of hard and porous surface layers with optimal pore distribution, which have increased hydrophilicity and potential ability to initiate deposition of apatite under physiological conditions within the body environment. Long-term stability of the implants requires both microporous surfaces and macroscopic structures of the implants. Overall, PEO with NTA can be used for manufacturing the next generation of dental/osseous implants.

\section{ACKNOWLEDGEMENTS}

This work was supported by the National Center for Research and Development, Poland, under research Project No. POIR.01.01.02-00-0022/16 and by the Ministry of Education and Science of Ukraine, grant no 0119U100823. SK received support from Erasmus+ Jean Monnet grant 599989-EPP-1-2018-1-UAEPPJMOMODULE.

9. V. Korniienko, O. Oleshko, Y. Husak, V. Deineka, V. Holubnycha, O. Mishchenko, A. Kazek-Kęsik, A. JakóbikKolon, R. Pshenychnyi, K. Leśniak-Ziółkowska, O. Kalinkevich, A. Kalinkevich, M. Pisarek, W. Simka, M. Pogorielov, Materials 13, 3913 (2020).

10. O. Oleshko, I. Liubchak, Y. Husak, V. Korniienko, A Yusupova, T. Oleshko, R. Banasiuk, M. Szkodo, I. MatrosTaranets, A. Kazek-Kęsik, W. Simka, M. Pogorielov, Materials 13, 4359 (2020)

11. P. Hartjen, A. Hoffmann, A. Henningsen, M. Barbeck, A. Kopp, L. Kluwe, C. Precht, O. Quatela, R. Gaudin, M. Heiland, R. E. Friedrich, C. Knipfer, D. Grubeanu, R. Smeets, O. Jung, In Vivo 32, 241 (2018).

12. R.C. Costa, J.G.S. Souza, J.M. Cordeiro, M. Bertolini, E. D. de Avila, R. Landers, E.C. Rangel, C.A. Fortulan, B. Retamal-Valdes, N. C. da Cruz, M. Feres, V.A.R. Barão, J. Colloid Interface Sci. 579, 680 (2020).

13. O.P. Terleeva, A.I. Slonova, A.B. Rogov, A. Matthews, A. Yerokhin, Materials 12, 2738 (2019).

14. C. Ma, J. Liu, X. Zhu, W. Xue, Z. Yan, D. Cheng, J. Fu, S. Ma, Sci. Rep. 10, (2020).

15. M.-G. Park, H.-C. Choe, J. Nanosci. Nanotechnol. 19, 1114 (2019).

16. A. Santos-Coquillat, M. Mohedano, E. Martinez-Campos, R. Arrabal, A. Pardo, E. Matykina, Mater. Sci. Eng. C 97, 738 (2019).

17. N. Doi, H. Takashima, M. Kinjo, K. Sakata, Y. Kawahashi, Y. Oishi, R. Oyama, E. Miyamoto-Sato, T. Sawasaki, Y. Endo, H. Yanagawa, Genome Res. 12, 487 (2002).

18. D. Bonvin, J. A. M. Bastiaansen, M. Stuber, H. Hofmann, M. M. Ebersold, RSC Adv. 7, 55598 (2017). 
19. A. Kazek-Kẹsik, I. Kalemba-Rec, W. Simka, Materials 12, 3002 (2019).

20. E. Wierzbicka, B. Pillado, M. Mohedano, R. Arrabal, E. Matykina, Metals 10, 916 (2020).

21. T.W. Clyne, S.C. Troughton, Int. Mater. Rev. 64, 127 (2019).

22. Q. Li, J. Liang, Q. Wang, Mod. Surf. Eng. Treat. (2013).

23. J. Li, X. Cui, G.J. Hooper, K.S. Lim, T.B.F. Woodfield, J. Mechan.l Behav. Biomed. Mater. 105, 103671 (2020).

24. J. Zhou, L. Zhao, Acta Biomater. 43, 358 (2016).

25. N. Gui, W. Xu, A.N. Abraham, D.E. Myers, E.L.H. Mayes, K. Xia, R. Shukla, M. Qian, J. Biomed. Mater. Res. - Part
A 106, 2020 (2018).

26. Q.-ming Zhao, X.-kang Li, S. Guo, N. Wang, W.W. Liu, L. Shi, Z. Guo, Mater. Sci. Eng. C 110, 110682 (2020).

27. W. Zhang, K. Du, C. Yan, F. Wang, Appl. Surf. Sci. 254, 5216 (2008).

28. H.M. Kim, T. Himeno, T. Kokubo, T. Nakamura, Biomaterials 26, 4366 (2005).

29. N. Slepickova Kasalkova, P. Slepicka, Z. Kolska, V. Svorcik, Wetting and Wettability (2015).

30. B.L. Pereira, A.R. da Luz, C.M. Lepienski, I. Mazzaro, N.K. Kuromoto, J. Mech. Behav. Biomed. Mater. 77, 347 (2018).

\title{
Новий розчин для електрохімічної модифікації поверхні титану
}

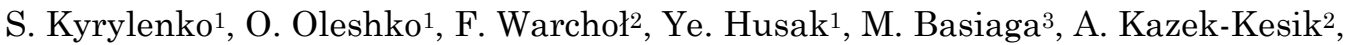 \\ G. Dercz ${ }^{4}$, M. Pogorielov ${ }^{1}$, W. Simka ${ }^{2}$
}

1 Medical Institute, Sumy State University, 2, Rymsky-Korsakov St., 40007 Sumy, Ukraine

2 Silesian University of Technology, Faculty of Chemistry, 44-100 Gliwice, Poland

3 Silesian University of Technology, Faculty of Biomedical Engineering, 41-800 Zabrze, Poland

${ }^{4}$ Institute of Materials Science, University of Silesia, 41-500, Chorzów, Poland

Дентальні та ортопедичні титанові імплантати е рутинним та доступним методом корекції в медичній практиці. Для подальшого підвищення безпеки та експлуатаційної довговічності досліджувались чисельні підходи щодо формування біоактивного поверхневого шару, який має забезпечити як підвищення остеоінгетращії, так і зменшити ризик бактеріальної індекції і формування бактеріальних біоплівок, які е предиктором розвитку периімплантитів. Плазмова електролітична оксидація (ПЕО) е перспективним методом формування біоактивного шару на металевих субстратах. Запропоновано різні протоколи ПЕО з метою досягнення кращої біосумісності дентальних імплантатів та підвищення їх стійкості до бактеріальних інфекцій, а також підвищення стійкості до корозії. При цьому процеси формування суцільних та пористих поверхневих шарів все ще потребують уточнення та детального вивчення. Попередні дослідження показали, що додавання хелатуючого агенту до електроліту призводить до кращих результатів, зокрема до формування пористої структури та підвищення функціональної здатності. В даному дослідження розкриті характеристики параметрів ПЕО з використанням електроліту, який містить інший широко використовуваний хелатуючий агент - нітрилотріоцтову кислоту (NTA), а також фоссрат калію та формут кальцію. Отримані результати сприятимуть подальшому розумінню механізмів процесу ПЕО та встановленню рутинних протоколів комерційної експлуатації методу.

Ключові слова: Плазмова електролітична оксидація, Титан, Біоактивна поверхня, Дентальні імплантати, Біосумісність, Скануюча електронна мікроскопія, Енерго-дисперсійна спектроскопія, Контактний кут. 